\title{
Blueberry Flower-bud Hardiness Is Not Estimated by Differential Thermal Analysis
}

\author{
Cindy L. Flinn ${ }^{1}$ and Edward N. Ashworth ${ }^{2}$ \\ Department of Horticulture, Purdue University, West Lafayette, IN 47907 \\ Additional index words. freezing injury, highbush blueberry, supercooling, $\mathrm{T}_{50}$, Vaccinium corymbosum
}

\begin{abstract}
Differential thermal analysis (DTA) was used to study the freezing behavior of 'Berkeley' blueberry (Vaccinium corymbosum $\mathrm{L}$.) flower buds at cooling rates of 10, 5, and $2 \mathrm{C} / \mathrm{hour}$. Experiments were conducted at various stages of hardiness on excised and attached $(5 \mathrm{~cm}$ of stem) buds. The presence and number of low-temperature exotherms (LTEs) in hardy buds generally increased when analyses were conducted using faster cooling rates with excised buds. The number of LTEs detected in individual buds did not correlate $\left(r^{2}=0.27\right)$ with the number of injured florets. The inability to detect LTEs in buds attached to stem segments and cooled at $2 \mathrm{C} / \mathrm{hour}$ indicates that DTA cannot reliably estimate blueberry flower-bud hardiness in field plantings.
\end{abstract}

Hardy flower buds of Rubus species (Warmund and George, 1990), forsythia [Forsythia $\times$ viridissima Lindl.] (Ashworth, 1990), grape [Vitis riparia Michx. (Pierquet et al., 1977)], [Vitis vinifera and hybrids (Quamme, 1986)], azalea [Rhododendron kosterianum, Schneid.] (George and Burke, 1977), pecan [Carya illinoensis (Wangenh.) C. Koch] (Rajashekar, 1989), and several Prunus species (Quamme, 1974) avoid freezing injury by deep supercooling. Although ice forms in the scales, water within the developing florets of these species remains liquid well below freezing temperatures (Ashworth, 1982, 1990; Quamme, 1978).

Differential thermal analysis (DTA) has been used to study the freezing of water within overwintering flower buds (Biermann et al., 1979; George and Burke, 1977; Ishakawa and Sakai, 1985; Pierquet et al., 1977; Quamme, 1986; Quamme et al., 1972). Two distinct freezing events have been detected in these and other tissues that supercool (Ashworth, 1982, 1990; Quamme, 1974, 1978, 1986; Rajashekar, 1989; Scarascia-Mugnozza et al., 1989). The first, known as the high-temperature exotherm (HTE), occurs just below $0 \mathrm{C}$ and is associated with the nonlethal formation of ice in bud scales and axis tissue (Ashworth, 1982; Graham and Mullen, 1976; Quamme, 1974). The second event, or low-temperature exotherm (LTE), occurs as water freezes in the developing floral organs and coincides with lethal injury. The number of LTEs detected in some species correlates with the number of frozen florets in each bud of Cornus officinalis (Ishikawa and Sakai, 1985) and rhododendron (George and Burke, 1977). Even in species in which the number of LTEs detected and the number of injured florets are not equal, the median LTE temperature has been found to closely approximate the critical temperature at which injury of $50 \%$ of the buds $\left(\mathrm{T}_{50}\right)$ occurs (Andrews and Proebsting, 1987; Ashworth, 1990; George and Burke, 1977; Graham and Mullen, 1976; Quamme, 1974, 1986; Warmund and George, 1990).

Although the correlation between LTE temperatures and field hardiness suggests DTA to be an accurate, quicker, and more efficient estimator of hardiness than conventional methods, the

Received for publication 22 Mar. 1993. Accepted for publication 6 July 1993 Journal paper no. 13434 of the Purdue Univ. Agricultural Experiment Station. We gratefully acknowledge the technical assistance of T. Willard and V. Stirm. We greatly appreciate the guidance and patience of C.E. Bracker in the preparation of this manuscript. The cost of publishing this paper was defrayed in part by the payment of page charges. Under postal regulations, this paper therefore must be hereby marked advertisement solely to indicate this fact.

${ }^{1}$ Graduate research assistant.

${ }^{2}$ Associate professor. reliability of exotherm profiles can be affected by tissue size and cooling rate. When DTA was conducted on a range of specimen sizes, nucleation occurred at lower temperatures in the smallest specimen masses of tomato stems (Anderson and Ashworth, 1985) and peach shoots (Ashworth and Davis, 1984; Ashworth et al., 1985). In excised flower buds, the HTE temperature was similarly affected (Ashworth, 1990; Gross et al., 1984; Scarascia-Mugnozza et al., 1989). Additionally, median LTE temperatures were higher in excised buds than in buds with attached stems (Ishikawa and Sakai, 1985; Quamme, 1986). Excessive cooling rates also have been shown to influence exotherm temperature. Ashworth et al. (1985) showed that nucleation occurred over time in peach shoots held at a constant freezing temperature. Therefore, cooling rates faster than field conditions could exaggerate the extent of supercooling. Conversely, median LTE temperatures increased when conifer primordial shoots (Sakai, 1982) and C. officinalis flower buds (Ishikawa and Sakai, 1985) were cooled at successively faster cooling rates. Therefore, a reliable estimation of hardiness depends on how closely the cooling rate and specimen size mimic field conditions.

DTA of blueberry flower buds detected multiple LTEs (Biermann et al., 1979). However, DTA was conducted on excised florets at cooling rates in excess of air cooling rates of 1 to $2 \mathrm{C} / \mathrm{h}$ in the field (Anderson and Ashworth, 1985; Levitt, 1980; Steffen et al., 1989). To determine whether DTA of blueberry flower buds attached to stems and conducted at a cooling rate of $2 \mathrm{C} / \mathrm{h}$ estimates freezing resistance of buds of intact plants in the field, we addressed the following questions: 1) Do LTEs occur in flower buds of intact blueberry plants subjected to natural cooling rates? 2) Does excision of stem tissue affect DTA profiles? 3) Can DTA be used to estimate accurately the resistance of blueberry flower buds to freezing under field conditions?

\section{Materials and Methods}

Plant material. 'Berkeley' blueberry terminal shoots, each bearing three to five buds, were periodically harvested from January 1990 through January 1991 and in December 1992 from Vander Molen's Blueberry Farm, Rensselaer, Ind. Samples were sealed in plastic bags, packed in ice, and transported to the laboratory. Samples that could not be processed immediately were stored in sealed bags at $4 \mathrm{C}$ for up to 2 days. When stored at this temperature, hardiness did not change during this interval. Before each experiment, leaves, if present, were removed. Stems of attached buds were left intact and trimmed to an overall length of 
$5 \mathrm{~cm}$, with at least $1.5 \mathrm{~cm}$ of stem below the proximal bud. Buds assigned to excision experiments were carefully trimmed to exclude stem tissue.

DTA. DTA was conducted as described by Quamme et al. (1972) on 10 flower buds attached to stem pieces and 12 excised flower buds. Each bud was taped to a 36-gauge (0.005-mmdiameter) copper-constantan thermocouple, enclosed in a small foil holder, and placed in a stoppered glass test tube. The tubes were then placed in an aluminum block housed in a $-80 \mathrm{C}$ freezer (Puffer Hubbard, New York), along with an oven-dried reference twig. Cooling rates of 2,5 , and $10 \mathrm{C} / \mathrm{h}$ were maintained by a resistance heater and a temperature programmer (Omega Engineering, Stamford, Conn.). Differential thermal output was recorded on a strip chart recorder (Linseis, Princeton, N.J.) (full scale, $0.5 \mathrm{mV}$ ). Mean number of exotherms and median LTE temperatures were calculated from the number of LTEs and the temperatures at which they occurred for each treatment combination.

Ice nucleation active (INA) bacteria were used to initiate freezing in selected experiments. Pseudomonas syringae strain W4N21 was cultured on Pseudomonas Agar F (Difco Laboratories, Detroit). A slurry of bacteria and deionized water was applied to distal ends of excised buds and stems of attached buds. Samples were immediately prepared for DTA as in other experiments and were cooled at $2 \mathrm{C} / \mathrm{h}$. In the three experimental replications, bacteria were applied to all samples in the first, none in the second, and to half in the third.

Hardiness determinations. Ten to 12 stem pieces with buds attached were placed in an aluminum foil packet lined with damp paper toweling. Twelve excised buds were placed into a second identical packet. Two packets were then sealed in a vacuum flask before freezing. Seven to ten flasks were then placed in a $-80 \mathrm{C}$ freezer. The cooling rate of specimens within the flasks, monitored by 24-gauge $(0.511$-mm-diameter) copper-constantan thermocouples, was $\approx 5 \mathrm{C} / \mathrm{h}$. Single flasks were removed over a range of temperatures chosen to yield a survival range of $0 \%$ to $100 \%$. Buds were allowed to thaw in sealed flasks at $4 \mathrm{C}$ and were then incubated for $48 \mathrm{~h}$ at room temperature. Flower buds were then dissected and inspected for blackened ovaries. The temperature at which $50 \%$ of the ovaries was killed $\left(\mathrm{T}_{50}\right)$ was determined by Bittenbender and Howell's (1974) adaptation of the SpearmanKärber equation.

In later determinations, excised buds and stems with attached buds were inoculated with INA bacteria to promote ice nucleation. The buds were then placed in stoppered glass test tubes with $0.5 \mathrm{ml}$ water and were cooled from 0 to $-40 \mathrm{C}$ at $2 \mathrm{C} / \mathrm{h}$ in a circulating bath (components from Neslab Instruments, Newington, N.H.). Bud temperatures were monitored with 24-gauge thermocouples. At $5 \mathrm{C}$ intervals, test tubes containing 10 stems with attached buds and

Table 1. Comparison of hardiness evaluations $\left(\mathrm{T}_{50}\right)$ of attached and excised blueberry flower buds during several winter seasons.

\begin{tabular}{lcc}
\hline \hline & \multicolumn{2}{c}{$\mathrm{T}_{50}$} \\
\cline { 2 - 3 } Date & $\begin{array}{c}\text { Attached } \\
\left(-{ }^{\circ} \mathrm{C}\right)\end{array}$ & $\begin{array}{c}\text { Excised } \\
\left(-{ }^{\circ} \mathrm{C}\right)\end{array}$ \\
\hline 9 Feb. 1990 & 29.9 & 22.5 \\
7 Mar. 1990 & 28.9 & 14.7 \\
22 Mar. 1990 & 20.4 & 8.1 \\
18 Dec. 1990 & 23.0 & 20.0 \\
15 Jan. 1991 & 20.0 & 20.0 \\
18 Dec. 1992 & 34.5 & 20.0 \\
\hline
\end{tabular}

12 excised buds were removed, incubated at $4 \mathrm{C}$, and examined for injury as in earlier determinations.

Correlation of LTEs with floret injury. To determine whether observed LTEs corresponded to the lethal freezing of individual florets, DTA was conducted on hardy excised buds at a cooling rate of $10 \mathrm{C} / \mathrm{h}$ (experimental conditions that produced many LTEs). Immediately after the appearance of at least three LTEs per bud, samples were removed from the freezer to room temperature and were incubated for $48 \mathrm{~h}$. The buds were dissected and examined for blackened ovaries. The number of dead florets per bud was regressed against the number of LTEs per bud to test the hypothesis that each LTE was associated with the freezing of one floret.

\section{Results and Discussion}

Stem excision. Over the course of three winters, the freezing resistance of excised blueberry flower buds, as estimated by $\mathrm{T}_{50}$, was less than that of buds attached to stems on all sampling dates except one; they were equal on 15 Jan. 1991 (Table 1). The greatest disparity in $\mathrm{T}_{50}$ values was $14.5 \mathrm{C}$, which occurred on 18 Dec. 1992 (Table 1).

A difference was noted in DTA profiles as well. In all buds, at least one distinct freezing event was detected. In the 1990-91 experiments, the HTE, a large initial peak, was detected between 0 and $-6 \mathrm{C}$ in attached buds with a median temperature of $-2 \mathrm{C}$ (Fig. 1). HTE temperatures of excised buds ranged from -5 to $-9 \mathrm{C}$, with a median temperature of $-7.5 \mathrm{C}$ (Fig. 1). When excised buds were treated with INA bacteria in later DTA experiments, nucleation occurred between -1.5 and $-2 \mathrm{C}$, the same range noted in untreated attached buds (data not presented).

Similar decreases in HTE temperatures were associated with stem excision in buds of forsythia (Ashworth, 1990), sweet cherry, and peach (Gross et al., 1984). Since HTE temperatures of excised blueberry buds treated with INA bacteria were identical to those of untreated buds attached to stems, one possible explanation is that ice nucleators, which are associated with woody tissue, are removed when the stem is excised (Gross et al., 1984). However, the overlap in HTE intervals of excised and attached blueberry buds suggests that, as in peach shoots (Ashworth et al., 1985), nucleation is a function of probability. Thus, larger specimens would have a higher probability of a nucleation event than smaller specimens. This hypothesis is further supported by the logarithmic relationship between nucleation and specimen size noted in stem

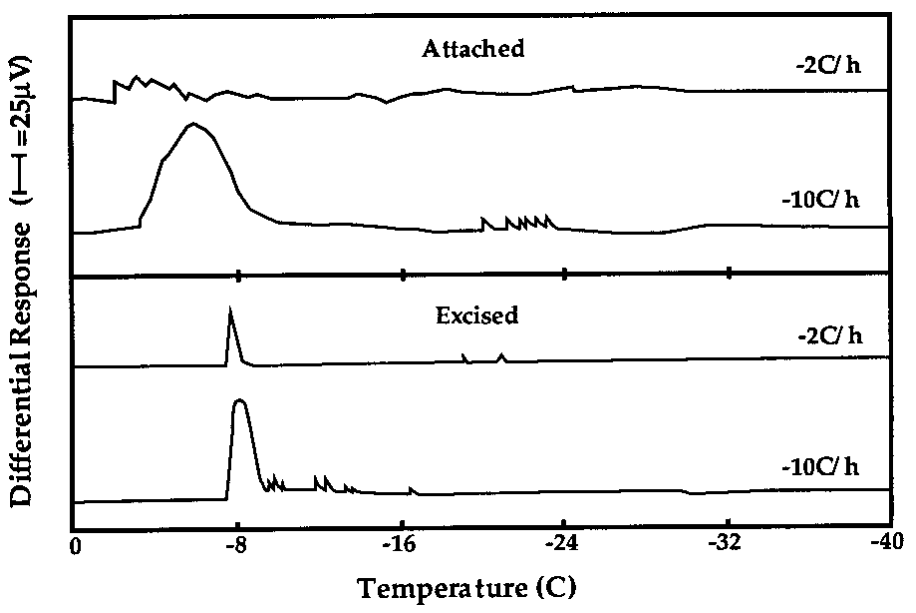

Fig. 1. Exotherm profiles of hardy blueberry flower buds with stems attached and excised buds. Tissues were cooled at 2 and $10 \mathrm{C} / \mathrm{h}$. Profiles were digitized from 9 Feb. 1990 differential thermal analysis plots. 
Table 2. Seasonal variation and rate dependency of median low-temperature exotherms (MLTEs) temperatures in attached and excised 'Berkeley' blueberry flower buds. Mean number of LTEs per bud is also given.

\begin{tabular}{|c|c|c|c|c|c|}
\hline \multirow[b]{3}{*}{ Date } & \multirow[b]{3}{*}{$\begin{array}{c}\text { Bud } \\
\text { treatment }\end{array}$} & \multicolumn{4}{|c|}{ Cooling rate } \\
\hline & & \multicolumn{2}{|c|}{$2 \mathrm{C} / \mathrm{h}$} & \multicolumn{2}{|c|}{$10 \mathrm{C} / \mathrm{h}$} \\
\hline & & $\begin{array}{c}\mathrm{MLTE}^{\mathrm{z}} \\
\left({ }^{\circ} \mathrm{C}\right)\end{array}$ & $\begin{array}{c}\text { Mean } \\
\text { no. LTEs }\end{array}$ & $\begin{array}{l}\text { MLTE } \\
\left(-{ }^{\circ} \mathrm{C}\right)\end{array}$ & $\begin{array}{c}\text { Mean } \\
\text { no. LTEs }\end{array}$ \\
\hline \multirow[t]{2}{*}{9 Feb. 1990} & Attached & $--^{y}$ & $0^{x}$ & $22.5 \pm 2.9$ & 10 \\
\hline & Excised & 9.3 & $<1$ & $14.2 \pm 3.1$ & 8 \\
\hline \multirow[t]{2}{*}{7 Mar. 1990} & Attached & --- & 0 & $9.9 \pm 2.3$ & 8 \\
\hline & Excised & $7.5 \pm 0.8$ & 3 & $9.1 \pm 0.5$ & 2 \\
\hline \multirow[t]{2}{*}{22 Mar. 1990} & Attached & --- & $<1$ & $6.9 \pm 2.4$ & 4 \\
\hline & Excised & $7.8 \pm 1.1$ & 2 & $9.6 \pm 0.3$ & 1 \\
\hline \multirow[t]{2}{*}{18 Dec. 1990} & Attached & --- & 0 & $20.5 \pm 0.6$ & 5 \\
\hline & Excised & --- & 0 & $11.8 \pm 1.4$ & 6 \\
\hline \multirow[t]{2}{*}{ 15 Jan. 1990} & Attached & --- & 0 & $23.6 \pm 0.9$ & 9 \\
\hline & Excised & 12.1 & 3 & $14.6 \pm 2.6$ & 8 \\
\hline
\end{tabular}

${ }^{\mathrm{z}}$ Median LTE temperature \pm SD.

yNo LTEs detected.

${ }^{\mathrm{x}}$ Mean number of LTEs per bud. The number of LTEs per bud ranged from 0 to 14 .

segments of tomato (Anderson and Ashworth, 1985) and peach (Ashworth and Davis, 1984). Although not examined in this study, this relationship could be verified by comparing equal-sized specimens.

The appearance and temperature of a second freezing event (or LTE) was also influenced by stem excision. Multiple small peaks typical of LTEs were detected in buds with attached stems only at the fastest cooling rate (Fig. 1, Table 2). Excised buds generally exhibited LTEs, except those cooled at 2C/h on 18 Dec. 1990 (Table 2) and 18 Dec. 1992 (data not presented). When buds were cooled at $10 \mathrm{C} / \mathrm{h}$, median LTE temperature of excised samples was higher than that of attached samples for all dates except 7 and 22 Mar. 1990 (Table 2).

Increases in median LTE temperatures were noted when stems were excised from flower buds of grape (Quamme, 1986), and Cornus officinalis (Ishikawa and Sakai, 1985). Peach flower buds also exhibited lower median LTE temperatures on select dates (Ashworth and Davis, 1987). The erratic response of flower buds that have been excised is further evidence that DTA of excised buds may not reliably reflect the freezing behavior of buds on intact plants.

Cooling rate. Although HTE temperatures were not influenced by cooling rates, LTEs were greatly affected (Fig. 1, Table 2). More LTEs were observed when buds were cooled faster (Fig. 1, Table 2). No LTEs were detected in attached buds cooled at $2 \mathrm{C} / \mathrm{h}$ (Table 2). In contrast, LTEs were detected in excised buds at the same cooling rate on all dates except 18 Dec. 1990 (Fig. 1, Table 2). Frequencies did not reflect the number of florets per bud. In later DTA experiments in which specimens were inoculated with INA bacteria to initiate freezing, no LTEs were detected in either excised or attached buds (data not presented).

The sensitivity of DTA to experimental conditions like cooling rate is species specific. Profiles of grape flower buds cooled at $1 \mathrm{C} /$ $\mathrm{h}$ were similar to profiles of buds cooled at $10 \mathrm{C} / \mathrm{h}$ (Quamme, 1986). In contrast, not only was median LTE temperature in conifer shoots cooled at $0.05 \mathrm{C} / \mathrm{min}$ lower than shoots cooled at $0.11 \mathrm{C} / \mathrm{min}$, no LTEs were detected at the slowest rate of $5 \mathrm{C} /$ day (Sakai, 1982). Previously, exotherm profiles of blueberry flower buds were shown to be rate dependent. Biermann et al. (1979) detected LTEs at cooling rates of 6.5 to $9 \mathrm{C} / \mathrm{h}$, but not at 33 and $65 \mathrm{C} /$ $\mathrm{h}$. In our study, the difference in profiles of buds cooled at $2 \mathrm{C} / \mathrm{h}$ and

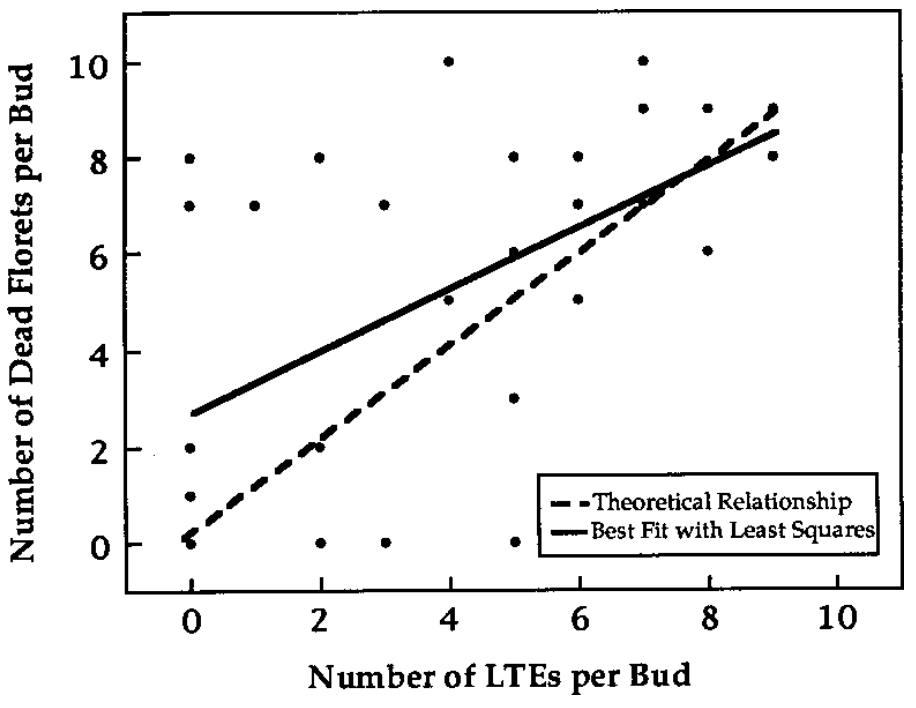

Fig. 2. Relationship between number of low-temperature exotherms (LTEs) and number of injured blueberry florets from interrupted differential thermal analysis conducted on excised buds at a cooling rate of $10 \mathrm{C} / \mathrm{h}$. Each point represents one bud. The dashed line represents the theoretical 1:1 relationship between LTEs and injured florets. The solid line represents the line of best fit as determined by least squares regression $(\mathrm{n}=30)$ with the following equation: $\mathrm{y}=3.4+0.5 \mathrm{x}$. An $r^{2}$ of 0.27 suggested no correlation between LTEs and floret injury.

those cooled at 10C/h (Fig. 1, Table 2) indicates that cooling rate may also influence the reliability of DTA as an estimator of field flower bud hardiness. Therefore, investigators should choose a cooling rate that is close to that of the 1 to $2 \mathrm{C} / \mathrm{h}$ cooling rate of the natural environment (Anderson and Ashworth, 1985; Levitt, 1980; Steffen et al., 1989).

Relationship between LTE and floret injury. LTEs were detected in blueberry flower buds only under certain conditions. When LTEs were detected, the median LTE temperature (Table 2) generally did not estimate hardiness $\left(\mathrm{T}_{50}\right)$ (Table 1$)$ in buds with or without stems attached, contrary to the previous blueberry study (Biermann et al., 1979). To determine whether these LTEs were associated with the death of individual florets, an interrupted DTA experiment was conducted on excised buds at a cooling rate of $10 \mathrm{C} / \mathrm{h}$, similar to experimental conditions used by Biermann et al. 
(1979). The number of LTEs detected did not correlate with floret injury $\left(r^{2}=0.27\right)$ (Fig. 2). Only in four of the 30 trials did the number of LTEs equal the number of injured florets (Fig. 2). In most of our trials (57\%), injured florets outnumbered the number of LTEs. The initial assumption that floret injury had occurred in the field was unlikely, since field injury in unfrozen controls of viability tests was minimal (one of 36 on 8 Feb. 1990 to zero on 24 Mar. 1990) on dates that bracketed this experiment. LTE detection could have been limited by the sensitivity of our equipment. However, in seven of 30 trials (Fig. 2), LTEs outnumbered injured florets. The extra LTEs, possibly resulting from the freezing of water in other bud tissues, suggested that at least $23 \%$ of our DTA profiles was misleading.

The lack of correlation in our study (Fig. 2) between LTEs, the number of injured florets, and $\mathrm{T}_{50}$ values was inconsistent with results reported previously in blueberry (Biermann et al., 1979). Buds of Rubus species (Warmund and George, 1990) and sweet cherry (Andrews and Proebsting, 1987) often produce fewer LTEs than injured florets. However, in both of these instances, the median LTE temperature was correlated with hardiness.

The primary objective of our study was to assess the overall reliability of DTA as an estimator of blueberry hardiness, a concept supported by a previous study (Biermann et al., 1979). We found no correlation between median LTE temperatures and $\mathrm{T}_{50} \mathrm{~s}$ (Tables 1 and 2). This disparity requires an explanation of the positive correlation reported in the previous study. Biermann et al. (1979) conducted DTA on excised buds, yet hardiness evaluations were based on buds attached to stem tissue. The median LTE temperature of excised buds should have been higher than the computed critical hardiness temperature based on our results that flower bud hardiness is greatly reduced when the stems are removed (Table 2). Additionally, Biermann et al. (1979) based critical hardiness temperatures on $66 \%$ survival rather than the more common $50 \%$ survival used in our study and in earlier studies of other species (Andrews and Proebsting, 1987; Bittenbender and Howell, 1974; George and Burke, 1977; Graham and Mullen, 1976; Quamme, 1974, 1986; Warmund and George, 1990). The resulting higher critical hardiness temperature could have lead the investigators to conclude that median LTE temperatures of blueberry correlated with bud hardiness.

How does the data gathered from the present study explain the freezing behavior in blueberry flower buds? Blueberry buds consist of eight to 12 florets arranged in a raceme on a common rachis. Unlike the multiple florets of sweet cherry (Quamme, 1974) and rhododendron (George and Burke, 1977), each blueberry floret is subtended by an inner bud scale or bract. This bract may serve as an ice sink during freezing. If so, an increase in bract moisture content would occur concomitantly with a decrease in the moisture content of developing florets, similar to the bud scales and primordium of C. officinalis (Ishikawa and Sakai, 1985) and sweet cherry (Andrews and Proebsting, 1987). Migration of water from the developing floret at the slowest cooling rate $(2 \mathrm{C} / \mathrm{h})$ would explain the lack of LTEs in blueberry and conifer shoots, a phenomenon termed extraorgan freezing by Sakai (1982). However, at faster cooling rates, LTEs seem to be an artifact of experimental protocol and do not reflect field conditions.

In this study, DTA of excised blueberry flower buds produced profiles different from those of intact tissues (Fig. 1). Also, a general lack of LTEs at $-2 \mathrm{C} / \mathrm{h}$ indicates that, under natural conditions, florets do not supercool. The flower buds may experience extraorgan freezing in which the water migrates toward ice sinks in the scales or bracts. Cooling rate also influences the appearance of exotherm profiles. From these experiments, we conclude that
DTA is not a reliable estimator of hardiness conditions of blueberry flower buds in the field.

\section{Literature Cited}

Anderson, J.A. and E.N. Ashworth. 1985. Ice nucleation in tomato plants. J. Amer. Soc. Hort. Sci. 110:291-296.

Andrews, P.K. and E.L. Proebsting. 1987. Effects of temperature on deep supercooling characteristics of dormant and deacclimating sweet cherry flower buds. J. Amer. Soc. Hort. Sci. 112:334-340.

Ashworth, E.N. 1982. Properties of peach flower buds which facilitate supercooling. Plant Physiol. 70:1475-1479.

Ashworth, E.N. 1990. The formation and distribution of ice within Forsythia flower buds. Plant Physiol. 92:718-725.

Ashworth, E.N. and G.A. Davis. 1984. Ice nucleation within peach trees. J. Amer. Soc. Hort. Sci. 109:198-201.

Ashworth, E.N. and G.A. Davis. 1987. Influence of ice nucleation temperature on the freezing of peach flower buds. HortScience 22:923925.

Ashworth, E.N., J.A. Anderson, and G.A. Davis. 1985. Properties of ice nuclei associated with peach trees. J. Amer. Soc. Hort. Sci. 110:287291.

Biermann, J., C. Stushnoff, and M.J. Burke. 1979. Differential thermal analysis and freezing injury in cold hardy blueberry flower buds. J. Amer. Soc. Hort. Sci. 104:444-449.

Bittenbender, H.C. and G.S. Howell. 1974. Adaptation of SpearmanKärber method for estimating the $\mathrm{T}_{50}$ of cold stressed flower buds. J. Amer. Soc. Hort. Sci. 99:187-190.

George, M.F. and M.J. Burke. 1977. Supercooling in overwintering azalea flower buds. Plant Physiol. 59:326-328.

Graham, P.R. and R. Mullen. 1976. The determination of lethal freezing temperatures in buds and stems of deciduous azalea by a freezing curve method. J. Amer. Soc. Hort. Sci. 101:3-7.

Gross, D.C., E.L. Proebsting, and P.K. Andrews. 1984. The effects of ice nucleation-active bacteria on temperatures of ice nucleation and freeze injury of Prunus flower buds at various stages of development. J. Amer. Soc. Hort. Sci. 109:375-380.

Ishikawa, M. and A. Sakai. 1985. Extraorgan freezing in wintering flower buds of Cornus officinalis Sieb. et Zucc. Plant Cell and Environ. 8:333338.

Levitt, J. 1980. Responses of plants to environmental stresses. vol. 1. 2nd ed. Academic Press, New York.

Pierquet, P., C. Stushnoff, and M.J. Burke. 1977. Low temperature exotherms in stem and bud tissue of Vitis riparia Michx. J. Amer. Soc. Hort. Sci. 102:54-55.

Quamme, H.A. 1974. An exothermic process involved in freezing injury to flower buds of several Prunus species. J. Amer. Soc. Hort. Sci. 99:311-314.

Quamme, H.A. 1978. Mechanism of supercooling in overwintering peach flower buds. J. Amer. Soc. Hort. Sci. 103:57-61.

Quamme, H.A. 1986. Use of thermal analysis to measure freezing resistance of grape buds. Can. J. Plant Sci. 66:945-952.

Quamme, H.A., C. Stushnoff, and C.J. Weiser. 1972. The relationship of exotherms to cold injury in apple stem tissue. J. Amer. Soc. Hort. Sci. 97:608-613.

Rajashekar, C.B. 1989. Deep supercooling in stem and bud tissues of pecan. HortScience 24:348-350.

Sakai, A. 1982. Extraorgan freezing of primordial shoots of winter buds of conifer, p. 199-209. In: P.H. Li and A. Sakai (eds.). Plant cold hardiness and freezing stress. vol. 2. Academic Press, New York.

Scarascia-Mugnozza, G., R. Valentiny, E. Kuzminski, and E. Giordano. 1989. Freezing mechanisms, acclimation processes and cold injury in Eucalyptus species planted in the Mediterranean region. For. Ecol. Mgt. 29:81-94.

Steffen, K.L., R. Arora, and J.P. Palta. 1989. Relative sensitivity of photosynthesis and respiration to freeze-thaw stress in herbaceous species. Plant Physiol. 89:1372-1379.

Warmund, M.R. and M.F. George. 1990. Freezing survival and supercooling in primary and secondary buds of Rubus spp. Can. J. Plant Sci. 70:893-904. 